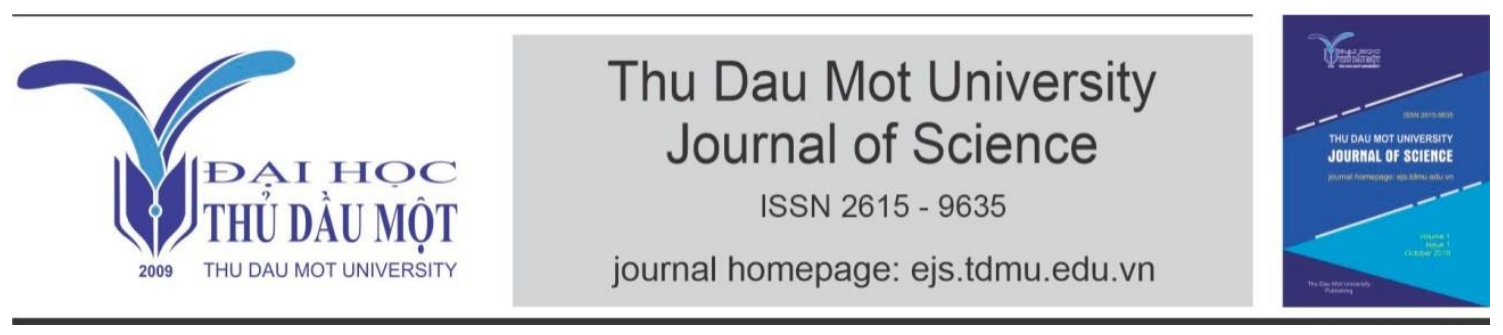

\title{
Effects of milling combined with extremely low-liquid ammonia (ELLA) pretreatment to enhance enzymatic hydrolysis of corn stover
}

by Truơng Nguyễn Phuơng Vi (Thu Dau Mot University)

\author{
Article Info: Received 5 Jan. 2021, Accepted 1 Mar. 2021, Available online 15 Mar. 2021 \\ Corresponding author: vitnp@tdmu.edu.vn \\ https://doi.org/10.37550/tdmu.EJS/2021.01.153
}

\begin{abstract}
Lignocellulosic biomass is one of the largest carbohydrate sources and has huge potential for biofuels production. However, the problem with lignocellulosic feedstock is that it has useful sugars locked in by lignin, hemicellulose, and cellulose. Some kind of pretreatment; therefore is needed to make carbohydrate accessible which later can be fermented to produce ethanol. The results from this research indicated that the yields of glucan (93\%) and xylan (82.8\%) were improved by using milling combined with ELLA pretreatment. The optimal enzymatic hydrolysis efficiencies were obtained under 10 min for ball milling time, pretreatment at $1 \mathrm{~h}$, temperature at $150^{\circ} \mathrm{C}, \mathrm{S} / \mathrm{L}=0.5$ and ammonia loading at $0.25 \mathrm{~g}-\mathrm{NH}_{3} / \mathrm{g}$-biomass. This method reduced the pretreatment time and short milling time and thus has potential of reducing the energy consumption and promising the application in the large scale.
\end{abstract}

Keywords: Corn stover, milling pretreatments, ammonia pretreatment, bioethanol

\section{Introduction}

Physical pretreatments are aimed to increase the accessible surface area of lignocellulosic biomass by reducing their particle size as milling pretreatment. Various milling methods such as ball milling, hammer milling and colloid milling can be used to mill biomass into powder. However, milling pretreatment consume high energy (Shaoni Sun et al., 2015). Alkaline pretreatment is the most commonly used method to remove 
lignin and hemicelluloses from lignocellulosic biomass and disperse bulk lignocellulosic material into lignocellulosic fibers (Shaoni Sun et al., 2015). Among alkaline pretreatments, ammonia treatments have been investigated most extensively for several reasons such as easy recovery, non-corrosiveness and non-toxicity (Jun Seok Kim et al., 2015). Studies revealed that a combination one or more pretreatments is more effective compared to pretreatment with chemical method alone. In the ammonia fiber explosion (AFEX) method, biomass is treated with liquid ammonia at high temperature and pressure to achieve effective pretreatment. Besides increasing the surface accessibility of cellulose for enzymatic hydrolysis, AFEX promotes cellulose recrystallization and partial hemicellulose depolymerization and reduces the lignin recalcitrance in the treated biomass (Balan V. et al., 2009).

In another study, an integrated wet-milling and alkaline pretreatment of corn stover using $\mathrm{NaOH}$ was applied (Xun He et al., 2009). Crystalline structure of corn stover was disrupted and lignin was removed, while cellulose and hemicellulose remained intact in corn stover by pretreatment with $1 \% \mathrm{NaOH}$ for $1 \mathrm{~h}$. $\mathrm{NaOH}(1 \%)$ pretreated corn stover had showed a holocellulose conversion value of $55.1 \%$ (He et al., 2009). Thus a combination of milling and alkaline pretreatment is considered to effective to improve the enzymatic hydrolysis and maximize the utilization of isolated hemicellulose and lignin (Shaoni Sun et al., 2015). In addition, the choice of a pretreatment process should not only be based on the yield of fermentable sugars upon saccharification but also should be based on other important parameters such as economic assessment and environmental impact. Reduction of pretreatment time is one of the vital factors for the industrial adoptability of the process. In this study, the impact of milling combined with extremely low-liquid ammonia (ELLA) pretreatment on enzyme effectiveness is studied and the best conditions for pretreatment as well as saccharification are deduced.

\section{Materials and methods}

\subsection{Materials}

\section{Feedstock}

Corn stover was supplied by CJ, Korea. The as received corn stover is air-dried at room temperature $\left(\sim 25^{\circ} \mathrm{C}\right)$ ground and sieved to a size at $10-35$ mesh. The initial composition of the biomass was determined by standard LAP (laboratory analytical procedure), by NREL. The initial composition of corn stover contained $33.0 \%$ glucan, $17.9 \%$ xylan, $3.2 \%$ arabinan, $1.9 \%$ galactan, $0.2 \%$ manan, $14.5 \%$ acid insoluble lignin, $2.1 \%$ acid soluble lignin, $0.9 \%$ ash, $6.0 \%$ protein on dry weight basis.

Enzyme 
Novozymes Cellic ${ }^{\circledR}$ Ctec2 (batch number: VCP10006) is used for the enzymatic hydrolysis of pretreated corn stover. The average activity of the enzyme, as determined by NREL, was 88.91 filter paper unit (FPU)/ml.

\subsection{Methods}

\section{Physical pretreatment}

Milling time is conducted for different time periods $(10-30 \mathrm{~min})$. The ratio between corn stover and alumina ball were based on volume/volume $(1 \mathrm{ml}$ of corn stover via 1 $\mathrm{ml}$ of balls in a cylinder).

\section{Alkaline pretreatment}

After the milling pretreatment, corn stover was treated with ammonium hydroxide by spraying. Ammonium hydroxide solutions were diluted in order to adjust ammonia loading at $0.25 \mathrm{~g}-\mathrm{NH}_{3} / \mathrm{g}$-biomass and solid to liquid ratio $1: 1$. The initial moisture content of corn stover is approximately $8.5 \%$. Then treated corn stover was stored in smaller sealed batch reactors with $30 \mathrm{~cm}$ length, $2.54 \mathrm{~cm}$ OD, and $0.21 \mathrm{~cm}$ tube wall thickness. Sealed batch reactors should be tightening carefully enough to prevent ammonia leaking. The ammoniated corn stover was pretreated at elevated temperatures $\left(120-180^{\circ} \mathrm{C}\right.$ for $\left.1-6 \mathrm{~h}\right)$. When the pretreatment is completed, reactors are cooled down to room temperature and opened for transferring the treated corn stover into a wide tray. Excess ammonia from the treated corn stover is evaporated in the fume hood for $1 \mathrm{~h}$ at $25^{\circ} \mathrm{C}$.

\section{Enzymatic hydrolysis}

The enzymatic digestibility of corn stover is determined in duplicate following National renewable energy laboratory analytical procedure (NREL LAP). Corn stover is treated at a $\mathrm{S} / \mathrm{L}$ ratio of $1 / 1\left(0.25 \mathrm{~g}-\mathrm{NH}_{3} / \mathrm{g}\right.$-biomass $)$ and a temperature of $120-180^{\circ} \mathrm{C}$ for $1-6$ h. The $250 \mathrm{ml}$ Erlenmeyer flasks with rubber caps were filled with $100 \mathrm{ml}$ liquid and 1.0 g glucan solid loading. The concentration of enzyme was 15 FPU/g-glucan per sample. Samples were tested in the Shaker Incubator (Vision Scientific Co., Ltd. Shaker Incubator, Model: VS $-8480 \mathrm{SFN})$ with stable conditions $\left(50^{\circ} \mathrm{C} \pm 1, \mathrm{pH} 4.8,150 \mathrm{rpm}\right)$. Approximately $1 \mathrm{ml}$ samples are collected from each flask every $24 \mathrm{~h}$. These samples are centrifuged 3 times and tested for sugars by HPLC (Shimadzu LC-10A) equipped with BioRad Aminex HPX-87H column and refractive index detector (RID-10A), mobile phase: water $(0.5 \mathrm{ml} / \mathrm{min})$, column temperature: $65^{\circ} \mathrm{C}$. The total glucose content after $72 \mathrm{~h}$ of hydrolysis was calculated and is a measure of the enzymatic digestibility. Untreated corn stover and Avicel ${ }^{\circledR}$ PH-101 (Lot \#BCBJ029V) are examined at the same digestibility test conditions as control samples. The glucan and xylan digestibility are computed as follow: 


$$
\begin{aligned}
& \text { Glucan digestibility }=\frac{\text { Total released glucose }(g) \times 0.9}{\text { Initial glucan loading }(g)} \times 100 \\
& X y \text { lan digestibility }=\frac{\text { Total released } x y \operatorname{lose}(g) \times 0.88}{\text { Initial xylan loading }(g)} \times 100
\end{aligned}
$$

0.9 is the conversion factor of glucose to equivalent glucan

0.88 is the conversion factors of xylose to equivalent xylan

\section{Results and discussion}

\subsection{Evaluation of combined effect of milling and ELLA pretreatment on compositions of corn stover}

The line chart shows the composition of corn stover after pretreatment at different conditions. Overall, it can be seen that total percentages of all components were steady. However, there were some changes between components such as ASL and AIL at $180^{\circ} \mathrm{C}$. (Fig.1). Besides, AIL and ASL contents had a significant rise when increasing the percentages during the pretreatment. For instance, AIL contents increased from $15.7 \%$ (untreated corn stover) to $19.5 \%$ (treated corn stover) and ASL contents increased from $2.3 \%$ to $6.1 \%$ at milling time of $10 \mathrm{~min}, 6 \mathrm{~h}$ and $180^{\circ} \mathrm{C}$.

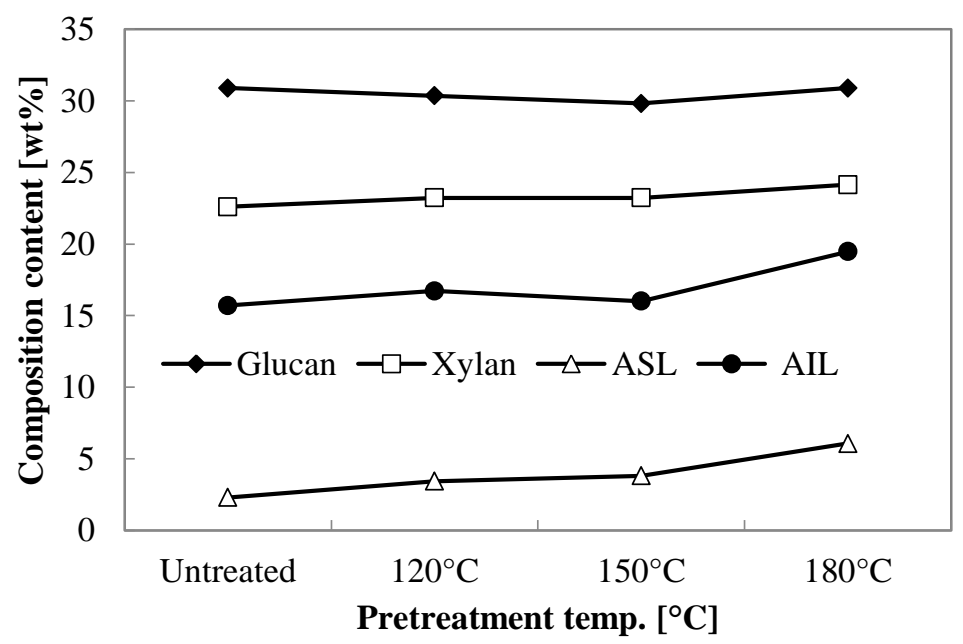

Figure 1. Compositions of corn stover after pretreatment from $120-180^{\circ} \mathrm{C}$. Conditions: milling time: $10 \mathrm{~min}$, pretreatment time: $6 \mathrm{~h}$, ammonia loading: $0.25 \mathrm{~g}$ $\mathrm{NH}_{3} /$ g-biomass, $\mathrm{S} / \mathrm{L}=0.5$.

\subsection{Evaluation of comybined effect of milling and ELLA pretreatment on enzymatic saccharification of corn stover}

In this experiment, milling and ELLA pretreatment has been set-up with the conditions 
of milling time from $10-30$ minute, increased the pretreatment temperature from $120-$ $180^{\circ} \mathrm{C}$, a reduced of pretreatment time from $1-6 \mathrm{~h}$. Table 1 shows the effect of milling time on enzymatic hydrolysis at different time. Overall, the glucan and xylan digestibility decreased. For examples, glucan and xylan digestibility of milling at 10 min are $93 \%$ and $84.8 \%$, respectively while untreated sample are $27.8 \%$ and $11 \%$, respectively. It can say that milling time can affect the pretreatment as we can see in Table 1, for instance, increasing the hydrolysis results. However, increasing milling time need to be considered as the obstacle because of the economic problem. Moreover, as in Table 2, there is no significant change in the enzymatic hydrolysis results among the milling time $(10-30 \mathrm{~min})(P$-value $>0.05)$.

$T A B L E$ 1. Enzymatic hydrolysis of corn stover before and after milling pretreatment at different time

\begin{tabular}{ccccc}
\hline & & \multicolumn{3}{c}{ Milling time } \\
\hline $\begin{array}{c}\text { Enzymatic hydrolysis } \\
{[\%]}\end{array}$ & Untreated & $\begin{array}{c}10 \\
{[\mathrm{~min}]}\end{array}$ & $\begin{array}{c}20 \\
{[\mathrm{~min}]}\end{array}$ & $\begin{array}{c}30 \\
{[\mathrm{~min}]}\end{array}$ \\
\hline $\begin{array}{cccc}\text { Glucan } \\
\text { Xylan }\end{array}$ & 27.8 & 93.0 & 93.1 & 96.4 \\
\hline
\end{tabular}

Conditions: milling time: 10 - $30 \mathrm{~min}$, pretreatment time: $1 \mathrm{~h}$, pretreatment temperature: $150^{\circ} \mathrm{C}$, ammonia loading: $0.25 \mathrm{~g}-\mathrm{NH}_{3} / \mathrm{g}$-biomass, $\mathrm{S} / \mathrm{L}=0.5$.

$T A B L E$ 2. ANOVA test of enzymatic digestibility of ELLA + milling treated solid for different milling time

\begin{tabular}{cccccc}
\hline $\begin{array}{c}\text { Enzymatic } \\
\text { hydrolysis } \\
{[\%]}\end{array}$ & $\begin{array}{c}\text { Milling time } \\
{[\mathrm{min}]}\end{array}$ & Low & High & $F$ & $P$-value \\
\hline \multirow{3}{*}{ Glucan } & 10 & 85.5 & 94.8 & & \\
& 20 & 82.6 & 94.5 & 0.2 & 0.7 \\
& 30 & 83.9 & 96.5 & & \\
\hline \multirow{2}{*}{ Xylan } & 10 & 58.7 & 82.1 & & \\
& 20 & 56.1 & 77.7 & 0.8 & 0.4 \\
& 30 & 56.8 & 71.6 & & \\
\hline
\end{tabular}

Conditions: milling time: 10 - $30 \mathrm{~min}$, pretreatment time: 1 - $6 \mathrm{~h}$, pretreatment temperature: $120-180^{\circ} \mathrm{C}$, ammonia loading: $0.25 \mathrm{~g}-\mathrm{NH}_{3} / \mathrm{g}$-biomass, $\mathrm{S} / \mathrm{L}=0.5$.

As shows in Table 3, between three different temperatures, $180^{\circ} \mathrm{C}$ gave the lower average glucan digestibility $(84.8 \%)$ than the others $\left(89.7 \%\right.$ at $120^{\circ} \mathrm{C}$ and $93.3 \%$ at $\left.150^{\circ} \mathrm{C}\right)$; meanwhile, there are a significant different meaning $(P$-value $=0.00)$ in glucan digestibility. Base on some previous research, it is inferred that the pretreatment temperature is one of the most considerable factors which can affect the enzymatic hydrolysis results.

$T A B L E$ 3. ANOVA test of glucan digestibility at different pretreatment temperature 


\begin{tabular}{ccccc}
\hline $\begin{array}{c}\text { Pretreatment temp. } \\
{\left[{ }^{\circ} \mathrm{C}\right]}\end{array}$ & Low & High & $F$ & $P$-value \\
\hline 120 & 86.6 & 92.8 & & \\
150 & 90.5 & 96.1 & 7.4 & 0.0 \\
180 & 77.7 & 91.8 & & \\
\hline
\end{tabular}

Pretreatment conditions: milling time: 10 - $30 \mathrm{~min}$, pretreatment time: 1 - $6 \mathrm{~h}$, pretreatment temperature: $120-180^{\circ} \mathrm{C}$, ammonia loading: $0.25 \mathrm{~g}-\mathrm{NH}_{3} / \mathrm{g}$-biomass, $\mathrm{S} / \mathrm{L}=0.5$.

However, too high temperature can not only reduces the results of glucan digestibility but also inhibits the enzymatic hydrolysis reaction due to the high concentration of lignin in the samples. In detail, at $180^{\circ} \mathrm{C}, 1-6 \mathrm{~h}$ of pretreatment time, and milling time of $10-30 \mathrm{~min}$, the glucan digestibility were lower by $80 \%$; parallel with that, the lignin content gave a statistically significance $(P$-value $=0.0)$ when lignin contents increased during the pretreatment, glucan digestibility decreased and inhibited (Table 4). As in previous study, the presence of lignin in the biomass inhibits hydrolysis of cellulose and hemicellulose (Ben GD et al., 1981), (Charlier et al., 2012), (Vidal and Molinier, 1988).

TABLE 4. ANOVA test of pretreatment temperature effect on lignin content in milling + ELLA treated solid

\begin{tabular}{ccccc}
\hline $\begin{array}{c}\text { Pretreatment temp. } \\
{\left[{ }^{\circ} \mathrm{C}\right]}\end{array}$ & Low & High & $F$ & $P$-value \\
\hline 120 & 15.8 & 19.4 & & \\
150 & 16.0 & 19.4 & 7.3 & 0.0 \\
180 & 18.2 & 23.8 & & \\
\hline
\end{tabular}

Conditions: milling time: $10-30$ min, pretreatment time: $1-6 \mathrm{~h}$, pretreatment temperature: $120-180^{\circ} \mathrm{C}$, ammonia loading: $0.25 \mathrm{~g}-\mathrm{NH}_{3} / \mathrm{g}$-biomass, $\mathrm{S} / \mathrm{L}=0.5$.

The summary of enzymatic hydrolysis at short pretreatment time of corn stover is showed in Table 5. It could be inferred that the results are above $80 \%$ for glucan digestibility. In addition, the high range of glucan digestibility results were achieved from $90.5-95.9 \%$ at $150^{\circ} \mathrm{C}$ (milling time $10-30 \mathrm{~min}$, pretreatment time $1-6 \mathrm{~h}$ ) compared to temperature of either 120 or $180^{\circ} \mathrm{C}$. The best result of glucan $(93.0 \%)$ and xylan digestibility $(82.8 \%)$ were obtained at shorter pretreatment time $(1 \mathrm{~h})$ by combined with milling for a short time of $10 \mathrm{~min}$. Furthermore, there is no significant different statistic when we changed the milling time $(P$-value $=0.7$ and 0.4$)$ as showed in Table 2 . The average of glucan digestibility at different milling time is approximately up to $90 \%$ at each condition $(10-30 \mathrm{~min})$. The optimal enzymatic hydrolysis efficiencies were obtained under $10 \mathrm{~min}$ for ball milling time, $1 \mathrm{~h}$ of pretreatment, temperature at $150^{\circ} \mathrm{C}, \mathrm{S} / \mathrm{L}=0.5$ and ammonia loading of $0.25 \mathrm{~g}-\mathrm{NH}_{3} / \mathrm{g}$-biomass.

TABLE 5. Summary of enzymatic hydrolysis of corn stover treated with milling combining with ELLA at a short pretreatment time 


\begin{tabular}{|c|c|c|c|c|c|c|}
\hline \multicolumn{5}{|c|}{ Pretreatment conditions } & \multicolumn{2}{|c|}{ Enzymatic hydrolysis at $72 \mathrm{~h}$} \\
\hline $\begin{array}{l}\text { Milling } \\
\text { time }\end{array}$ & $\begin{array}{l}\text { Ammonia } \\
\text { loading }\end{array}$ & $\mathrm{S} / \mathrm{L}$ & Temp. & Time & Glucan & Xylan \\
\hline$[\mathrm{min}]$ & [g/g-biomass] & {$[-]$} & {$\left[{ }^{\circ} \mathrm{C}\right]$} & {$[\mathrm{h}]$} & [\%] & [\%] \\
\hline \multirow{9}{*}{10} & \multirow{9}{*}{0.25} & \multirow{9}{*}{0.5} & \multirow{3}{*}{120} & 1 & $85.3 \pm 1.3$ & $80.1 \pm 1.3$ \\
\hline & & & & 3 & $89.1 \pm 2.5$ & $68.6 \pm 0.9$ \\
\hline & & & & 6 & $93.5 \pm 1.8$ & $68.9 \pm 0.5$ \\
\hline & & & \multirow{3}{*}{150} & 1 & $93.0 \pm 1.0$ & $82.8 \pm 1.1$ \\
\hline & & & & 3 & $96.0 \pm 0.2$ & $69.7 \pm 2.1$ \\
\hline & & & & 6 & $93.9 \pm 2.1$ & $63.3 \pm 0.2$ \\
\hline & & & & 1 & $89.9 \pm 1.4$ & $83.8 \pm 1.6$ \\
\hline & & & \multirow[t]{2}{*}{180} & 3 & $88.8 \pm 1.8$ & $71.3 \pm 1.0$ \\
\hline & & & & 6 & $81.2 \pm 1.7$ & $67.1 \pm 1.4$ \\
\hline \multirow{9}{*}{20} & \multirow{9}{*}{0.25} & \multirow{9}{*}{0.5} & \multirow{3}{*}{120} & 1 & $84.5 \pm 1.9$ & $68.7 \pm 0.3$ \\
\hline & & & & 3 & $88.9 \pm 1.7$ & $61.4 \pm 1.0$ \\
\hline & & & & 6 & $91.9 \pm 0.4$ & $62.6 \pm 2.5$ \\
\hline & & & \multirow{3}{*}{150} & 1 & $93.0 \pm 1.4$ & $70.7 \pm 1.8$ \\
\hline & & & & 3 & $92.2 \pm 1.1$ & $67.1 \pm 0.7$ \\
\hline & & & & 6 & $93.7 \pm 1.6$ & $69.4 \pm 0.4$ \\
\hline & & & \multirow{3}{*}{180} & 1 & $90.5 \pm 0.7$ & $81.4 \pm 1.4$ \\
\hline & & & & 3 & $87.3 \pm 1.0$ & $76.5 \pm 1.6$ \\
\hline & & & & 6 & $74.6 \pm 1.7$ & $68.7 \pm 1.7$ \\
\hline \multirow{9}{*}{30} & \multirow{9}{*}{0.25} & \multirow{9}{*}{0.5} & \multirow{3}{*}{120} & 1 & $90.0 \pm 0.9$ & $61.8 \pm 2.3$ \\
\hline & & & & 3 & $91.5 \pm 2.1$ & $64.9 \pm 1.2$ \\
\hline & & & & 6 & $92.3 \pm 0.2$ & $57.7 \pm 0.3$ \\
\hline & & & \multirow{4}{*}{150} & 1 & $96.3 \pm 0.6$ & $60.4 \pm 1.3$ \\
\hline & & & & 3 & $86.8 \pm 1.7$ & $69.1 \pm 2.6$ \\
\hline & & & & 6 & $94.4 \pm 1.7$ & $58.4 \pm 1.3$ \\
\hline & & & & 1 & $94.5 \pm 0.3$ & $75.2 \pm 1.0$ \\
\hline & & & \multirow{2}{*}{180} & 3 & $75.2 \pm 0.3$ & $63.8 \pm 2.5$ \\
\hline & & & & 6 & $80.6 \pm 0.3$ & $67.0 \pm 2.3$ \\
\hline
\end{tabular}

\subsection{Mass balance}

Figure 2 summarizes the mass balance of sugar production from corn stover using milling + ELLA method. At the best conditions (milling time at $10 \mathrm{~min}, \mathrm{~S} / \mathrm{L}=0.5,0.25$ g- $\mathrm{NH}_{3} /$ g-biomass, $150^{\circ} \mathrm{C}, 1 \mathrm{~h}$ ). Corn stover was milled at $10 \mathrm{~min}$, after that pretreated with high temperature $\left(150{ }^{\circ} \mathrm{C}\right)$ for 1 hour. When corn stover was treated at the aforementioned conditions, ammonia recovery was approximately $98 \%$ and the residual ammonia was $2 \%$. Then the pretreated solid was hydrolyzed with $15 \mathrm{FPU}$ of Ctec2/gglucan enzyme loading. The highest glucan and xylan digestibilities were $93.0 \%$ and $82.8 \%$, respectively. 


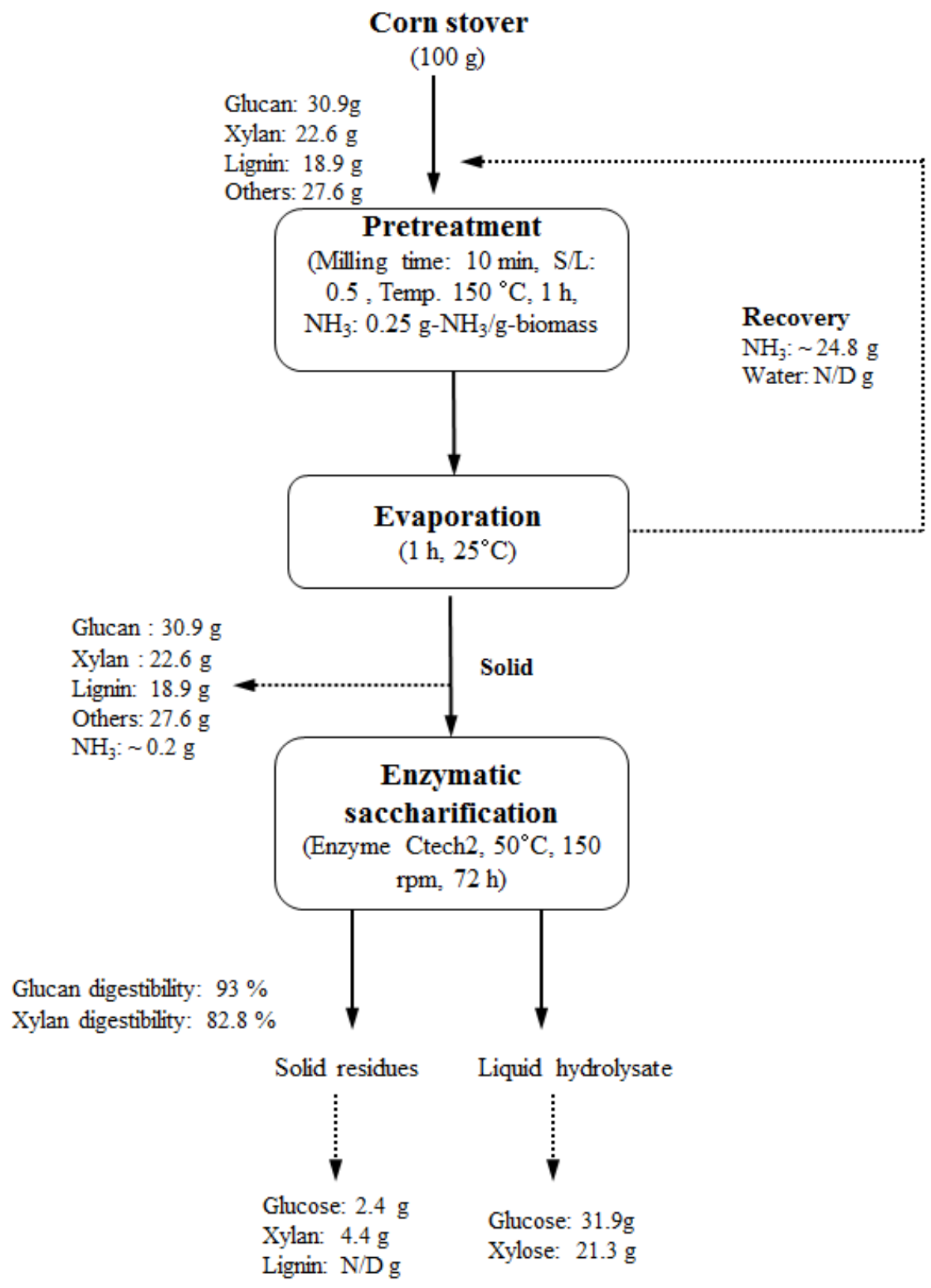

Figure 2. Mass balance of corn stover combined milling + ELLA pretreatment.

\section{Conclusion}

Extremely low liquid ammonia pretreatment can be successfully carried out at ambient conditions, however, higher temperature are required if the pretreatment is needed to be carried out for shorter pretreatment time. In addition, in some previous experiments, best results were obtained when milling was combined with alkaline pretreatment method. For examples, ball milling-treated bagasse and straw produced $78.7 \%$ and $72.1 \%$ and $77.6 \%$ and $56.8 \%$, glucose and xylose, respectively (Sant Ana Silva et al., 
2010). In another study, oil palm frond fiber when pretreated through ball mill produced glucose and xylose yields of $87 \%$ and $81.6 \%$, respectively, while empty fruit bunch produced glucose and xylose yields of $70 \%$ and $82.3 \%$, respectively (Zakaria et al., 2014). The table 6 shows the optimization of pretreatment conditions on time, temperature and method. The data also demonstrates that ball milling pretreatment combined with ELLA pretreatment is a promising method. From the 3rd experiment, it could be observed that enzymatic hydrolysis results are increased; meanwhile, the results indicate that the effect of milling combined with ELLA pretreatment can improve the enzymatic hydrolysis at short pretreatment time and therefore, reducing the operation costs. The optimal enzymatic hydrolysis efficiencies were obtained under 10 min for ball milling time, pretreatment at $1 \mathrm{~h}$, temperature at $150^{\circ} \mathrm{C}, \mathrm{S} / \mathrm{L}=0.5$ and ammonia loading at $0.25 \mathrm{~g}-\mathrm{NH}_{3} / \mathrm{g}$-biomass.

TABLE 6. Optimized pretreatment processes for enzymatic digestibility of corn stover

\begin{tabular}{ccccccc}
\hline $\begin{array}{c}\text { Number of } \\
\text { experiment }\end{array}$ & $\begin{array}{c}\text { Milling } \\
\text { pretreatment }\end{array}$ & \multicolumn{2}{c}{ ELLA pretreatment } & \multicolumn{2}{c}{ Enzymatic hydrolysis } \\
\hline Milling time & $\begin{array}{c}\text { Ammonia } \\
\text { loading } \\
{\left[{\mathrm{g}-\mathrm{NH}_{3} / \mathrm{g}-}^{\text {biomass }]}\right.}\end{array}$ & Time & Temp. & Glucan & Xylan \\
\cline { 3 - 7 } & {$[\mathrm{min}]$} & - & - & - & 22.0 & {$[\%]$} \\
\hline Untreated & - & - & - & - & 43.6 & 16.6 \\
\hline 1 & 10 & 0.16 & 24 & 90 & 91.8 & 72.6 \\
2 & - & 0.25 & 1 & 150 & 84.7 & 69.3 \\
3 & 10 & 0.25 & 1 & 150 & 93.0 & 82.8 \\
\hline
\end{tabular}

\section{References}

Ayla Sant'Ana da Silva, Hiroyuki Inoue, Takashi Endo, Shinichi Yano, Elba P.S. Bon. (2010). Milling pretreatment of sugarcane bagasse and straw for enzymatic hydrolysis and ethanol fermentation. Bioresource Technology 101, 7402-7409.

Balan V., Bals B., Chundawat SP., Marshall D., Dale BE. (2009). Lignocellulosic biomass pretreatment using AFEX. Biofuel, Volume 581 of the series Method in Molecular Biology pp 61-77.

Hyeon Jeong Kim, Jeong Ho Chang, Bong-Yong Jeong, Jin Hyung Lee. (2013). Comparison of milling modes as a pretreatment method for cellulosic biofuel production. Journal of Clean Energy Technologies, Vol. 1, No. 1.

Jun Seok Kim, Y.Y. Lee, Tae Hyun Kim. (2015). A review on alkaline pretreatment technology for bioconversion of lignocellulosic biomass. Bioresource Technology 199 (2016) 42-48

P.F.H. Harmsen, W.J.J. Huijgen, L.M. Bermudez Lopez, R.R.C. Bakker. (2010). Literature review of physical and chemical pretreatment processes for lignocellulosic biomass. Wageningen University \& Research centre - Food \& Biobased Research.

Sant' Ana daSilva A, Inoue H, Endo T, Yano S, Bon EPS (2010) Milling pretreatment of sugarcane bagasse and straw for enzymatic hydrolysis and ethanol fermentation. Biores Technol 101:7402-7409. 
Shaoni Sun, Shaolong Sun, Xuefei Cao, Runcang Sun. (2015). The role of pretreatment in improving the enzymatic hydrolysis of lignocellulosic material. Bioresource Technology (2016) 49-58.

Xun He, Yelian Miao, Xuejian Jiang, Zidong Xu, Pingkai Ouyang. (2009). Enhancing the enzymatic hydrolysis hydrolysis of corn stover by an integrated wet-milling and alkaline pretreatment. Applied Biochemistry and Biotechnology, Volume 160, Issue 8, pp 24492457.

Zakaria MR, Fujimoto S, Hirata S, Hassan MA (2014) Ball milling pretreatment of oil palm biomass for enhancing enzymatic hydrolysis. Appl Biochem Biotechnol 173:1778-1789

http://link.springer.com/protocol/10.1007\%2F978-1-60761-214-8_5 